UDC 339

\title{
THE INFLUENCE OF COUNTRY RISK ON FOREIGN DIRECT INVESTMENT: THE EMPIRICAL STUDIES ON EMERGING MARKETS IN EAST ASIA SUMMIT
}

\author{
Sappar Bildiosta*, Suhadak, Wijaya Ari Darmawan \\ Post-graduate Program, Faculty of Administrative Science, University of Brawijaya, Indonesia \\ ${ }^{\star}$ E-mail: bildiosta.mba.ub.id@gmail.com
}

\begin{abstract}
This research aims to make exploration from the formation of country risk structure in emerging markets country, and the influence of every risk dimension on intake flow of Foreign Direct Investment (FDI). Country risk concept was formed based on the three major dimensions, i.e. political risk, economic risk, and financial risk. This research determined investment intake flow through FDI inward flows and stocks. The subjects of this research were 3 largest countries in the world, i.e. China, Thailand, and Indonesia, as emerging markets country selected to represent East Asia Summit. The research result revealed that political risk influenced FDI intake flow, the influence between other risks had different result variance in different country. The result also indicated that each country's risk dimension had various result on FDI intake flow, this showed the difference of risk characteristic. That condition was possible to happen because of the difference on manifest variable forming structure within risk dimension in every country. Specific overview of each country's risk gave interesting result towards risk component and FDI flow intake in every country.
\end{abstract}

\section{KEY WORDS}

Emerging markets, county, risk, foreign investments.

According to the World Bank, international trade dynamic is divided into several classifications, i.e. advance economic, emerging and developed countries, other countries, and global assessment. Consideration of exported transaction value usage in internation trade is at the moment of exported value is part of government revenue from goods or service trade result excluding host country. The position of international trade during the observation period is stable but there is tendency to decrese, in which trend flat is indicated to the countries entering into the classififcation of emerging and developed countries.

A dynamic change from international trade is truly related to the global economic events, especially economic growth. View on classical economics lieracy, explained by Barro and Martin (2004) in Economic Growth book, tells the vast majority of countries in the world tries to create prosperity by improving economic growth. Economic growth can provide stimulus to every country to make an effort to improve competitive superirority in international trade, economy, financial, and policy from every country. Economic growth can be illustrated from the increase of ability to produce dometic product through growth value of Gross Domestic Product (GDP). The increase of country's ability to produce goods and services can give stimulus to increase income from exported fied.

Positive economic growth in a country shows the existence of good economics and domestic finance activity. According to the global economics data, it is in the down trade poition started in 2007-2009. Economic growth during 2010-2016 experienced dynamic increase and decrease, but not at a high range compared to the previous decade period. According to that condition, previous country's growth propectus can provide an illustraton of not good global growth condition; it experiences fluctuation and global economics deceleration.

International trade and foreign investment flows do not only give economics value but also is used as knowledge transfer source, performance, and technology, especially from industrial country to the developing ones, which give positive value from trade externality and investment. FDI flows movement according to UNCTAD-STAT in the classification of high income, middle income, and global assessment showsfluctuactive condition, especially in 
2008-2010, caused by global economic crisis. In 2015-2016, international investment got slow, this condition happened since the international investor, both capital venture and international banking tended to perform a "wait and see" decision to invest in a country.

East Asia Summit (EAS) is an international forum which nowadays is grouped into East Asia Country. Actually, this forum discusses several aspects in the scope of states, trade relationship, economics partnership, and social aspect among the member country. Several parts of EAS performance in Phillipines in 2007 united the Minister of Finance and Economy of each country and invitation to strengthen economic integration of East Asia. Several important issues discussed were about uncertainty condition of global economics still give a challenge on several years later. The general finding of this research is to give joint contribution to increase economics fundamental to each country through trade integration and keep stability of finance transaction among the country, especially to become a fitness to invest countries.

FDI is an international portfolio product for investor to make a cross-country investment and become an opportuntity of investor benefit. Generally, foreign investor tends to choose to invest in form of FDI, compared to other capital forms in a country. FDI inflow and outflow can be influenced from the condition of receiver country (pull factors) or stratety consideration of foreign investment (push factors). Pull factors of the enter of FDI are among others market condition, resources availability, competitiveness, policy related to the trade and industry as well as liberalization policy of FDI (in form of investment incentive).

FDI flows potential in emerging markets countries are much related to the risk that must be faced by shareholder who will invest in a country. Shareholder, both investor in an international security, Multinational Corporation (MNC), and the government institution have to conduct diversification of risk since the existence of difference risk in every country. Fundamental analysis becomes a basis concept to predict investment risk. There is perspective of inverted pyramid on the analysis of fundamental which one of them is called top-down anaysis, it tells about how to consider assessment in a general or macro point of view and tapers into more specific things like internal condition of a country.

Dynamic changes, economy, financial, and political condition between country can result in an effect to the international investment. This happens because of domestic condition stability so that can increase investor's trust to a country. International investmet is the major element of industrial development and economic growth in a host country, in addition to as form of capital inflows, foreign investment has spillover effect as form of externalization from the agglomerazion in form of local-skilled labour pooling, input sharing and knowledge spillover formed through industry collection of a country and causes economic scale.

This research offers risk construction mapping using country risk (CR) concept to influence the change of FDI intake flow in a country. A study conducted by Hoti and McAleer (2004,p. 584-585) reviewed several appraisal agencies both methodology and research variable to determine risk level, using qualitative and quantitative approach in collecting the data of economic risk, financial risk, and political risk. This research aims to test the relevance and practicality risk literature to the assessment of risk potential of emerging markets country, through the country risk model and criteria and econometric criteria that have been determined in the estimation model, evaluation and estimation are conducted to the FDI flows of emerging market country in EAS.

\section{LITERATURE REVIEW}

Country risk understanding is commonly proposed by Nagy (1989, as cited in Glova, 2014 , p. 101), they give an illustration of loss on cross-border lending loan happened as the result of an event or a condition of a country with limited border, under the control of the government not an individual or company. According to Cosset et al. (1992) explained by Glova (2014, p. 107), country risk is a probability of a country's failure to result in an enough devisa to meet the obligation to the foreign creditor. Specifically, it needs to have a wider understanding of a better definition which is in accordance with country multidimentional risk 
characteristic. International juridically, according to Bouchet et al. (2003), there is no international concencus that specifically explaines comprehensive definition of country risk. Country risk, in today's literature, can be connected to the international investment risk, with general term as "cross-border risk" or "sovereign risk".

The needs of assessment of risk of each country which will be a location for investment faced by global world especially trade and international finance flow is stated by Krayenbuehl (1985) explained by Hoti and McAleer (2004, p. 540) shows that, "The need for a detailed assessment of country risk and its impact on international business operations is crucial. Country risk refers broadly to the likelihood that a sovereign state or borrower from a particular country may be unable and/or unwilling to fulfil their obligations towards one or more foreign lenders and/or investors."According to the condition of states' internal instability, risk assessment to the investment has became an important aspect in a strategy selection decision, and a manager can form country risk analysis as advice (guidance) in providing foreign investment decision (Oetzel et al., 2001; Bouchet et al., 2003).

According to Oetzel et al. (2001) explained by Brown et al. (2014, p. 2) "A risk might be a concern because of potential short-term profit losses for one organization, because of human suffering for another, and because of national security threats to yet another."A risk might be a concern because of potential short-term profit losses for one organization, because of human suffering for another, and because of national security threats to yet another.According to several literacies on classical understanding from country risk studied by Clark and Marois (1996) and Miller (1998) explained by Liu et al. (2016, p. 234-245), there are two different perceptions, firstly showing that country risk covers to different situation, referring to the foreign business activity and at the specific risk with various risk sources and its industrial characteristic. Another opinion is proposed by Bouchet et al. (2003), explaining that every form of investment has a particular feature or transaction type, it needs a whole perspective from source and risk type having a possibiity to affect different economy.

This research also provides literature review on the relationship between country risk and trade and international investment. International trade is an external activity of a country and company in fulfilling domestic needs and raw material, so that externalization concept is essential in the aspect of trade and international investment. International investment means a strategy of selecting global-based investment instrument as part of invesment portfolio. Interntional investment generally covers to investment product like investment fund, deposit, traded funds in stock exchange or direct investment in foreign market. According to Krugman (2012, p. 184), international investment have two main purposes, i.e. diversification, in which investor both multinational corporation and country or an individual investing internationally aims to conduct diversification as risk share of investment between company and foreign market.

Assests allocation is generally an investment strategy aims to blance risk and award by dividig assests of portfolio in accordance with individual's aim, risk tolerance and investment. Deversification itself is conducted to predict and avoid not systematical risk event in a portfolio so that positive performance from several invesments neutralize negative performance on different portfolio. Diversification in international investment has a basis addopting various perceptions of investment principles. That is representative of investment principles generally proposed, i.e. "High Risk High Return", "Time Value of Money", dan "Do not put your money in one basket".

This research offers risk assessment construct relating to the FDI intake flow of a country. Main component selection of country risk is considered under the recommendation of Erb et al. (1996, p.7), and developed by Hoti and McAleer (2004, p. 584-585 and 2006. p. 691-714) on the model of International Country Risk Guide (ICRG) ranking. The Handbook of Country and Politca Risk Analysis (Coplin and O'Leary, 1994) provides reflective illustration from political risk, economic risk, and financial risk in a country risk concept. That model is also used by Liu et al. (2016, p. 234-245) in their research.

An understanding on political risk according to Cullen et al. (2010, p. 311) was that "political riskassesses political stability in areas such as civil unrest, war, terrorism, and 
changing regulations". Vijayakumar et al. (2009, p. 183) provides view on political risk as "apossibility that political decisions, events, or conditions in a country, including those that might be referred to as social, will affect the business environment such that investors will lose money or have a reduced profit margin".Political condition assessment especially respond from the government of a country, proposed by Brown et a. (2014, p. 20) explaines that governence (political) assessment in a conceptual and country risk new management can be seen from the stability of government management of a country, both in terms of policy and procedural of technical in a political stability.

According to Kaufman et al. (2010, p. 3-5), government means tradition and institution having authority in a state where the policy applied, policy assessment of the government in a political stability was explained that, "(a) The process by which governments are selected, monitored and replaced, (b) The capacity of the government to effectively formulate and implement sound policies, and (c) The respect of citizens and the state for the institutions that govern economic and social interactions among them."According to the reccommendation from Kaufmann et al. (2010), this research considered the use of manifest variable for political risk construction, i.e, political stability and Absenc of Terrorism, Regulatory Quality, Rule of Law, and Voice and Accountability.

Understanding on economic risk, according to Cullen et al. (2010, p. 311), is how internal economic strength of a country to give benefit value or risk to investment. Economic risk is one of the reasons of international investment brings risk more than domestic investment as consideration of decision making. Economic risk also gives opportunity for investor, while bonds or foreign protfolio enables investor to participate directly to the foreign currency market and the environmetn of different country's interest rate. According to the reccomendation of a study conducted by Brown et al. (2014), Nordal (2001), Hoti and McAleer (2004) Hoti and McAleer (2006), and Liu et al. (2016), and Sanjo (2012), it is important to use manifest variable of rinancial risk construction, i.e. GDP Growth, Current Account Balance, Inflation Rate, Unemployement, and Total Tax Rate.

Understanding on financial risk according to Cullen et al. (2010, p. 311), tell that state finance management give a perspective on the ability of country's debt management. Financial risk is considered ability of a country to make a decision in terms of account payables financing and various obligations. This research uses debt perspective on the public sector recommended in the study conducted by Brown et al. (2014), Liu et al.(2016), Hoti and McAleer (2004 and 2006), and Liu et al. (2016), with manifest variiable assessment for financial risk construct, i.e. Central Governmnt Debt, Total Debt Service, gross Domestic Saving, Interest rate spread, and Exchanges Rates.

FDI studies growing into the wider are macroeconomic. Aggregately, FDI level will influence states economic of FDI receiver in various concentration, among other production (output), labor, unemployement rate, income, price, import, economic growth, sales balance sheet, and general welfare of receiver country. Investment form in the context of international is commonly conducted by MNC that can engage at field of manufacture, processing industry, natural resources exploration, service industry, and etc. At an economic perception, FDI is important part of global economic system. According to the reccomendation of the study conducted by Nordal's (2001), Vijayakumar et al.(2009), Hayakawa et al. (2013), and Busse et al. (2007), who considers manifest variable selection to assess international investment in the perspective of FDI, i.e. inward, flows, and inward stocks.

\section{METHODS OF RESEARCH}

This was quantitative explanatory research. The use of explanantory research aims to explain a generalizion sample towards population or explain relationship, difference or influence of a variable and other variables. Quantitative model is used to fathom and process information in form of statistics analysis data to give risk construction illustration towards FDI flow. This research collected sample from a country classified as emerging markets selested from EAS, under the characteristic of the country considered in this research, i.e. China, Thailand, and Indonesia. This research used secondary data from 2007 until 2016 (10 years) 
obtained from World bank, IMF, and UNCTAD-STAT. Data analysis used was Variancebased Structural Equation Modelling (SEM) - Partial Least Square (PLS) with WarpPLS as tools calculate, which can work more efficient with relatively small sample, complex mode, and being able to conduct analysis to reflective assessment model.

\section{RESULTS AND DISCUSSION}

The importance of assessment from model fit and quality indices in the research construction model to know the worthiness of a structure model obtained. According to Kock (2017), data processing using warPLS resuts in Average Path Coefficient (APC), Average RSquare (ARS), Average Adjusted R-Square (AARS), Tenenhaus GoF (GoF), Simpson's Paradox ratio (SPR), R-Square Contribution Ratio (RSCR), Statistical Suppression Ratio (SSR), and Nonlinear Bivariate causality Direction Ratio (NLBCDR). Assessment from variable coefficient evaluation can use the result of coefficient asessment of determinant and predictive validity.

Determinant coefficient with $\mathrm{R}$-square value indicating the average model of research construction get score bigger than 0.5 . It is only at a construction model assessment of Thailand at an equation of economic risk results in value smaller than 0.5 . Q-square value at the whole capital has higher value than 0 , so that construct model of the research gives good model relevance. Assessment result of model fit and quality (Table 1), and variable coefficient evaluation (Table 2 and Table 3 ) showed that the whole value has met classification as structural model fitness that can be used for optimal model in hypothesis test.

Assessment from variable coefficient of this research uses assessment of determinant coefficient and predictive validity (Table 2 and 3 ). Determinant coefficient uses R-square showing that average result of construction model gets higher score than 0.5 . The result of determinant coefficient in the research can be explained that the percentage of variance of endogeneous/criterion construct for hypothesis considered moderate to give illustration of influence from exogenous variable. It is only at assessment of construction model of Thaliand and Russia at latent variable for economic risk equation results in lower score than 0.5 . That condition is possibleto happen because the complexity of risk assessment applied in that country is not represented by manifest variable of this research. Q-square value of the whole model has higher value than 0 , so that predictive validity of construction model can predict relevantly of the model used in this hypothesis test.

Table 1 - Model Fit and Quality Indices of Construct Model

\begin{tabular}{|c|c|c|c|c|c|c|c|c|}
\hline \multirow{2}{*}{ Country } & \multicolumn{8}{|c|}{ Model Fit } \\
\hline & APC & ARS & AARS & GoF & SPR & RSCR & SSR & NLBCDR \\
\hline China & 0.007 & $\leq 0.001$ & $\leq 0.001$ & 0.814 & 0.833 & 0.981 & 1.000 & 1.000 \\
\hline Thailand & 0.013 & 0.002 & 0.006 & 0.608 & 1.000 & 1.000 & 1.000 & 0.833 \\
\hline Russia & 0.010 & 0.001 & 0.001 & 0.676 & 1.000 & 1.000 & 1.000 & 1.000 \\
\hline Indonesia & 0.013 & $\leq 0.001$ & $\leq 0.001$ & 0.753 & 0.833 & 0.963 & 1.000 & 1.000 \\
\hline
\end{tabular}

Description:

- $\quad A P C, A R S$, and AARS state the whole confirmed p-value has had significant value less than 0.5.

- $\quad$ GoF value shows higher score than 0.36.

- $\quad S P R$ vale indicates score approching 1 or higher than 0.7 .

- $\quad R S C R$ value shows higher score than 0.9 or ideal by 1 .

- $\quad$ SSR, RSCR and NLBCDR value indicates score higher than 0.7.

Table 2 - R-square of Construct Model

\begin{tabular}{lllll}
\hline Country & PR & ER & FR & FDI \\
\hline China & - & 0.678 & 1.0 & 0.848 \\
Thailand & - & 0.367 & 0.806 & 0.733 \\
Russia & - & 0.44 & 0.81 & 0.912 \\
Indonesia & - & 0.815 & 0.874 & 0.519 \\
\hline
\end{tabular}

Notes: political risk (PR), economic risk (ER), financial risk (FR), and Foreign Direct Investment (FDI). 
Eurasia: Economics \& Business, 4(10), April 2018

DOI https://doi.org/10.18551/econeurasia.2018-01

Table 3 - Q-square Coefficients of Construct Model

\begin{tabular}{lllll}
\hline Country & PR & ER & FR & FDI \\
\hline China & - & 0.731 & 0.889 & 0.953 \\
Thailand & - & 0.397 & 0.744 & 0.697 \\
Russia & - & 0.383 & 0.837 & 0.91 \\
Indonesia & - & 0.828 & 0.75 & 0.727 \\
\hline
\end{tabular}

Notes: political risk (PR), economic risk (ER), financial risk (FR), and Foreign Direct Investment (FDI).

According to the statistical analysis, it got a result that hypothesis test (Table 4) gave a specific enough result variance which in constructing risk structure in China, Thailand, Russia, and Indonesia. The result gotten from emerging markets country showed that it has completely a significant influence of political risk influence on risk economic in each emerging markets country. That finding was supported by the study conducted by Erb et al. (1996, p. 10-12) telling that the changes happened between political risk and economic risk was assesed having linear increase or decrease.

Empirically, this research found difference from influence form, positive form in China and Russia, while negative influence in Thailand and Indonesia. It explained that the respond from political risk to economic risk for every country has a variance on influence form among latent variable. This condition was also found in the research result by Erb et al, (1996, p. 1012 ), and Hoti and McAleer (2004, p. 540), stating that the condition could not always apply to the others, even tough there was rate changes togetherly both decrease and increase. Variable assessment conducted in the same period was able to have different assessment perspective.

Table 4 - The Test Result of the Effect of Each Research Latent Variable

\begin{tabular}{|c|c|c|c|c|c|c|}
\hline Hypothesis & Effect & Statistics & China & Thailand & Russia & Indonesia \\
\hline \multirow{4}{*}{$\mathrm{H} 1$} & \multirow{4}{*}{$\mathrm{PR} \rightarrow \mathrm{ER}$} & P. Coefficient & 0.823 & -0.606 & 0.663 & -0.903 \\
\hline & & t statistic & 5.276 & -3.223 & 3.704 & -6.185 \\
\hline & & $\mathrm{P}$ value & $\leq 0.001$ & 0.005 & 0.002 & $\leq 0.001$ \\
\hline & & Explanation & Significant & Significant & Significant & Significant \\
\hline \multirow{4}{*}{$\mathrm{H} 2$} & \multirow{4}{*}{$\mathrm{PR} \rightarrow \mathrm{FR}$} & P. Coefficient & 0.152 & 0.499 & -0.814 & 0.938 \\
\hline & & t statistic & 0.547 & 2.422 & -5.185 & 6.652 \\
\hline & & $\mathrm{P}$ value & 0.299 & 0.019 & $\leq 0.001$ & $\leq 0.001$ \\
\hline & & Explanation & Not Significant & Significant & Significant & Significant \\
\hline \multirow{4}{*}{$\mathrm{H} 3$} & \multirow{4}{*}{$\mathrm{ER} \rightarrow \mathrm{FR}$} & P. Coefficient & 1.055 & -0.502 & 0.352 & -0.076 \\
\hline & & t statistic & 8.242 & -2.449 & 1.504 & -0.257 \\
\hline & & $\mathrm{P}$ value & $\leq 0.001$ & 0.019 & 0.083 & 0.402 \\
\hline & & Explanation & Significant & Significant & Not Significant & Not Significant \\
\hline \multirow{4}{*}{$\mathrm{H} 4$} & \multirow{4}{*}{$\mathrm{PR} \rightarrow \mathrm{FDI}$} & P. Coefficient & -0.434 & 0.231 & 0.486 & 0.158 \\
\hline & & t statistic & -1.991 & 0.892 & 2.337 & 0.572 \\
\hline & & $\mathrm{P}$ value & 0.039 & 0.198 & 0.022 & 0.291 \\
\hline & & Explanation & Significant & Not Significant & Significant & Not Significant \\
\hline \multirow{4}{*}{ H5 } & \multirow{4}{*}{$\mathrm{ER} \rightarrow \mathrm{FDI}$} & P. Coefficient & 0.054 & -0.592 & -0.284 & -0.595 \\
\hline & & t statistic & 0.179 & -3.116 & -1.145 & -3.132 \\
\hline & & $P$ value & 0.431 & 0.006 & 0.141 & 0.006 \\
\hline & & Explanation & Not Significant & Significant & Not Significant & Significant \\
\hline \multirow{4}{*}{$\mathrm{H} 6$} & \multirow{4}{*}{$\mathrm{FR} \rightarrow \mathrm{FDI}$} & P. Coefficient & -0.612 & -0.397 & -0.395 & -0.153 \\
\hline & & t statistic & -3.273 & -1.764 & -1.756 & -0.552 \\
\hline & & $\mathrm{P}$ value & 0.005 & 0.056 & 0.057 & 0.297 \\
\hline & & Explanation & Significant & Not Significant & Not Significant & Not Significant \\
\hline
\end{tabular}

Notes: political risk (PR), economic risk (ER), financial risk (FR), and Foreign Direct Investment (FDI).

The test results empirically show that most of the countries give a significant response to the effect of political risk to financial risk, except for china. The result of Petrovic's research (2009, p. 12), matches some of the test result which back up the claim that there is a significant effect of political risk to financial risk. The policy of one country to govern their debt ratio also depicts their national interest. This implication can be seen at the time the national debt policy is executed. For instance, the decision made in one period to fulfill one 
nation's responsibility which require a great number of nominal will restrict the process of political decision related to state budgeting in the next period.

The result of lloie's research (2015, p. 632) shows that the correlation between political risk to financial risk from the changes of state budgeting matrix yields a possible reason, namely the changes of political policy and political risk. The changes of governance policy causes the instability of political condition. Politic and budget stability are the result of a series of government policy that yields high quality policy, private sector stability and national security, especially in handling global economic issues. State budgeting stability is deeply related with a steady budgeting system which gives a better economic endurance to economic condition of foreign countries by carrying out the intermediation function effectively.

This research empirically shows that not all of the countries give the same response to the effect of economic risk to financial risk. The research performed by Krayenbuehl (1985), Hoti and McAleer (2004, p. 540), and Sanjo(2012, p. 300) explains that one sovereign state that loan to a particular country is possible to choose to have the ability to fulfill the responsibilities or not. The consideration of economic stability indicates the ability of one country to manage their economic power to fulfill their responsibilities set forth in treaty contract.

A linear change, both economic and financial risk, implies that a better economic condition at certain point indicates a decrease rate of economic risk. Economic stability in medium term is a good chance to one country to have a better income. This income can also be classified as public sector income. The increase of the income in one country is not only for domestic needs but also for developing people's trust towards the country to fulfill their responsibilities.

This research empirically shows that not all of the countries give the same response to the effect of political risk to FDI. The research conducted by Brewer et al. (1990), Hoti and McAleer (2004, p. 540), Erb et al. (1996, p. 12-13), Nordal (2001, p. 197), Vijayakumar et al. (2009, p. 198), and Busse et al. (2007, p. 412-413) shows political risk as one of dimensions in assessing country risk influencing the supply and the cost of capital flows. The influence of political risk also disclose a better correlation of economic risk to invest return rate. Political risk particularly gives the greatest influence of the most total risk for investor in a developing country.

The research conducted by Krayenbuehl (1985), Petrovic (2009, p. 12), Hayakawa et al. (2013, p. 60 ), Iloie (2015, p. 628), and Liu et al., (2016, p. 244), shows that political risk refers to the risk of government policy of host country where the enterprises invest. Suggesting Country Risk Assessment evaluates the analysis of decision making related to potential risk and business income. The other result disclose that the country's risk can be decomposed to some components of risk, one of them is political factor which significantly affects international investor by giving active response to host country.

This research empirically shows that not all of the countries give the same response to the effect of economic risk to FDI. The research performed by Juttner (1995), Hoti and McAleer (2004), Vijayakumar et al. (2009, p. 189), lloie (2015, p. 628), and Liu et al., (2016, p. 244) support some part of the research result, where the consideration of economic condition of one country is able to affect free flow of capital or give an immediate changes to expected risk-return features of investment This condition indicates that there are changes to investor's and creditor nation's interest which caused by the economic indicator changes of a country.

In another view related to the cost factor imposed by investor and MNC in gaining their income, there are some differences in their expectation. Tax competition between nations becomes a long term consideration for enterprises' ability to gain profit and cost of capital in their first investment. The comprehension of FDI flows stated by Moosa (2002 p. 24-40), in the differential rate of return hypothesis, explained that capital swiftly flows from a country with a low return rate to the country with a higher return rate. In this case, FDI is determined based on marginal return and marginal cost. 


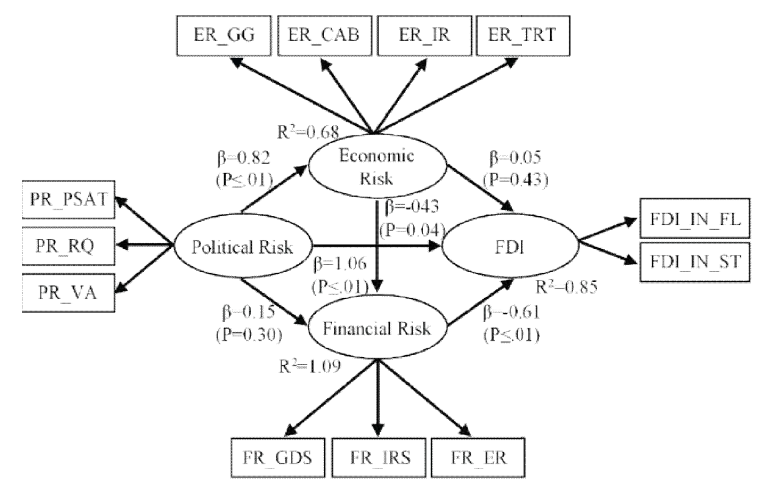

Figure 1 - China

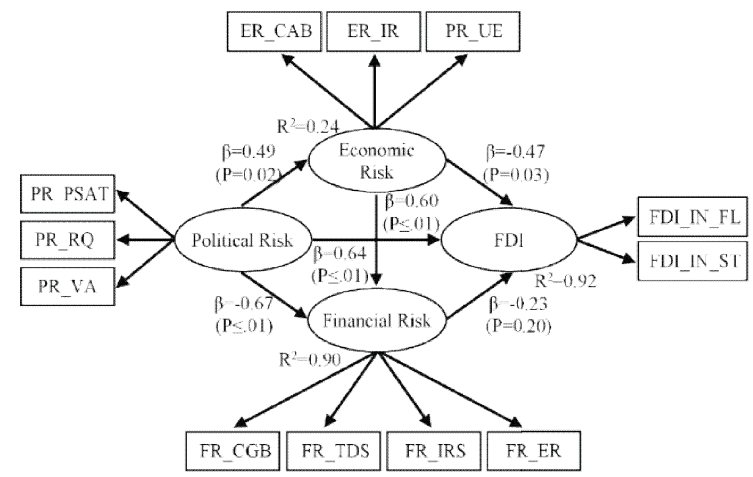

Figure 3 - Russia

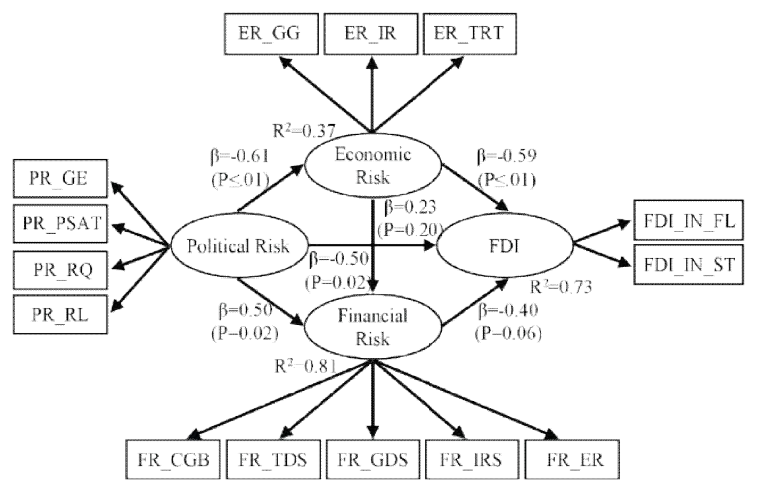

Figure 2 - Thailand

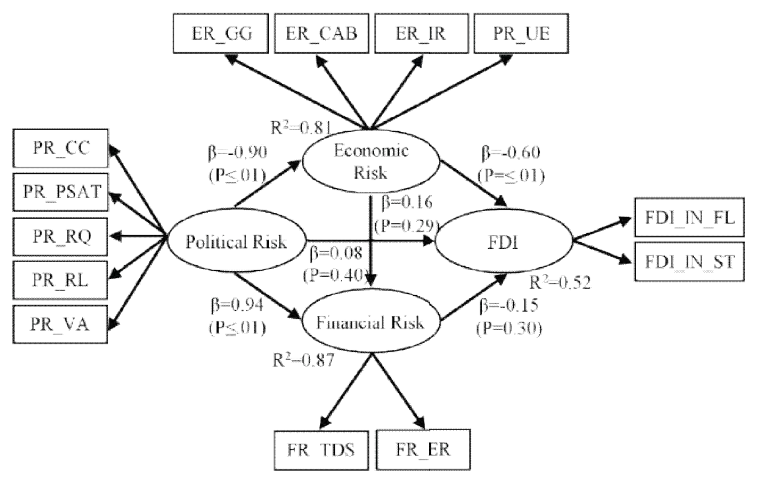

Figure 4 - Indonesia

Notes: The symbols on the figure could be described as follows, $\beta$ (beta), $P$ ( $P$ value), $R^{2}$ (R-square) control of corruption (PR_CC), government effectiveness (PR_GE), political stability and absence of terrorism (PR_PSAT), regulatory quality $\left(P R \_R Q\right)$, rule of law (PR_RL), voice and accountability (PR_VA), GDP Growth (ER_GG), current account balance (ER_CAB), inflation rate (ER_IR), unemployment (ER_UE), total tax rate (ER_TR), central government debt (FR_CGB), total debt service (FR_TDS), gross domestic savings (FR_GDS), interest rate spread (FR_IRS), exchanges rates (FR_ER), FDI inward flows (FDI_IN_FL), and FDI inward stocks (FDI_IN_ST).

Table 5 - Risk Structure of Each Country

\begin{tabular}{ll}
\hline Variable & Country \\
\hline Political Risk & Indonesia \\
Control of Corruption & Thailand \\
Government Effectiveness & \\
Political stability and & All Country \\
absence of terrorism & \\
Regulatory Quality & Indonesia \\
Rule of Law & China, and Indonesia \\
Voice and Accountability & \\
Economic Risk & Thailand, Russia, and Indonesia \\
GDP Growth & China, Thailand, and Indonesia \\
Current Account Balance & All Country \\
Inflation Rate & Russia, and Indonesia \\
Unemployment & China, and Thailand \\
Total tax rate & \\
Financial Risk & Russia \\
Central Government Debt & Thailand, Russia, and Indonesia \\
Total debt service & Thailand \\
Gross Domestic Saving & China, Thailand, and Russia \\
Interest rate spread & All Country \\
Exchanges rates & \\
FDI & All Country \\
FDI Inward Flows & \\
FDI Inward Stocks &
\end{tabular}


This research empirically shows that most countries have tendency to give a same response to the effect of financial risk to FDI. The research conducted by Brewer et al. (1990), Juttner (1995), Hoti and McAleer (2004, p. 540) explained that financial risk is part of country risk assessment to influence foreign capital flows with designated supplies and costs. Azeez's (2015, p. 1-11), and Petrovic (2009, p. 12) research explains that the correlation between the debt management and FDI are significantly needed by the emerging-market country, and explains that the interconnection between the country risk dimension and the FDI of domestic and foreign enterprise. According to Moosa (2002, p. 24-40) in the diversification hypothesis, investment decision of a project is not only determined by the return rate but also the risk.

Optimum construction model, depicts the indicator that have a tendency to form a risk structure on each nation (Figure 1 for 4 and Table 5) Research result finds a tendency of political stability and absence of terrorism indicator in forming a construction model of political risk on each country. Control of corruption, government effectiveness, regulatory quality, rule of law, and voice and accountability indicator, are varies on each country. There is also a tendency of inflation rate in forming economic risk construction model in a country. Although GDP Growth and current account balance have a similar tendency, but they cannot absolutely be implemented to economic risk construction, and they are different with unemployment and total tax rate indicator.

Research result finds a tendency of exchange rates indicator in forming a construction model of financial risk on each country. Total debt service and interest rate spread indicator have a similar tendency but cannot absolutely be applied to economic risk construction. While central government debt and gross domestic savings indicator have different variant on each nation. FDI construction gives an absolute explanation of manifest variable forming construction model, namely inward flows and stock FDI, in assessing income flows of foreign investment of a country.

\section{CONCLUSION}

This research successfully depicts construction risk on emerging-market countries at EAS. This research result can be used as reference to all capital owner with multidimensional perspective of latent variable by considering risk on each emerging-market country. This research gives political, economic and financial risk perspective to give different consideration of risk structure on each country. Different risk level and dimensional risk give a specific perspective in dealing with different FDI inward flows on each country. The use of historical data for a decade, can be intended to both medium and long term business strategic decision making.

The government of the countries of research sample have an opportunity to consider each dimensional and country risk to decrease risk level having dominant influence to the changes of FDI inward flows. Improving political, economic and state budget stability are able to give different impact to each country. This condition is an opportunity of each country to improve their competence, interest and trust to capital owner in international investment market.

The use of analysis model to assay the effect of country risk to FDI requires a better manifest variable selection from reflective variables. Political risk variable which commonly be seen from governance perspective requires risk assay from domestic business act, while economic and financial risk are considered as premium risk. FDI latent variable are assessed by using FDI outward flows and stocks to see the response to FDI outward flows or the decrease of country risk level.

The future research may consider research samples from emerging-market countriesor a member of internal association having bilateral and economic relationship such as Association of Southeast Asian Nations (ASEAN), Asia Pacific Economic Creative (APEC), Asian Development Bank (ADB), European Union (EU), ASEAN Free Trade Area (AFTA), American Free Trade Agreement (NAFTA) etc. This consideration is to have a wider perspective regarding risk assessment on each country in an economic area. The use of 
data research will be used to determine a better validity, especially in the scale used on each research data. In addition, the data will be used to have more dependable composition of manifest variable on each latent variable.

\section{REFERENCES}

1. Azeez, B., Oladapo, F., Aluko, A., \& Olufemi. (2015). External Debt or Foreign Direct Investment Which Has Greater Significant Economic Impact on Nigeria. European Scientific Journal, 11(19), 185-195

2. Barro, R. J., Martin, S., \& Xavier. (2004).Economic Growth. London: Cambrige The MIT Press.

3. Bouchet, M. H., Clark, E., \& Groslambert, B. (2003) .Country Risk Assessment: A Guide to Global Investment Strategy. England: John Wiley and Sons Ltd.

4. Brewer, T. L., \& Rivoli, P. (1990). Politics and Perceived Country Credit Worthiness in International B nking. Journal of Money, Credit and Banking, 22(3), 357-369.

5. Brown, C. L., Cavusgil, S., Tamer., \& Lor, A. W. (2014). Country-risk Measurement and Analysis, New Conceptualization and Managerial Tool. International Business Review, 24(2), 1-20.

6. Busse, M., \& Hefeker, C. (2007) .Political Risk, Institutions and Foreign Direct Investment. European Journal of Political Economy, 23 (2), 397-415.

7. Clark, E., \& Marois, B., (1996). Managing Risk in International Business, Techniques and Applications. London: International Thomson Business Press.

8. Coplin, W. D., \& Oleary, M. K. (1994).The Handbook of Country and Political Risk. New York: Political Risk Services.

9. Cosset, J.C., Siskos Y., \& Zopounidis, C. (1992). Evaluating Country Risk, A Decision Support Approach. Global Finance Journal, 3(1), 1-79.

10. Cullen, J. B., Parboteeah, K., \& Praveen. (2010) .International Business, Strategy and the Multinational Company. New York: Routledge.

11. Erb, C. B., Campbell, R., Harvey., Tadas, E., \& Viskanta et.al. (1996) .Political Risk, Economic Risk and Financial Risk. Financial Analysts Journal, 52(6), 1-41.

12. Glova, J. (2014). Country Risk in The CESEE Countries, Fundamental Beta Approach. Procedia Economics and Finance, 15(11), $100-107$.

13. Hayakawa, K., Kimura, F., \& Lee, H. H. (2013). How Does Country Risk Matter For Foreign Direct Investment?.The Developing Economies, 51(1), 60-78.

14. Hoti, S., \& McAleer, M. (2004). An Empirical Assessment of Country Risk Ratings and Associated Models.Journal of Economic Surveys, 18(4), 1-50.

15. Hoti, S., \& McAleer, M. (2006). How Does Country Risk Affect Innovation?An Application to Foreign Patents Registered in The USA. Journal of Economic Surveys, 20(4), 1-24.

16. Iloie, R. E. (2015). Connections between FDI, Corruption Index and Country Risk Assessments in Central And Eastern Europe. Procedia Economics and Finance, 32(84), 626-633.

17. Juttner, D. J. (1995). Risk Premia In Foreign Exchange and Interest Rates In International Finance and Global Investments (3rd ed). Melbourne: Longman.

18. Kaufmann, D., Kraay, A., \& Mastruzzi, M. (2010). The Worldwide Governance Indicators, Methodology And Analytical Issues. Policy Research Working Paper, 54(30), 1-31.

19. Kock, N. (2017). Warp PLS User Manual Version 6.0. Texas: ScriptWarp Systems.

20. Krayenbuehl, T. E. (1985). Country Risk Assessment and Monitoring. Toronto: Lexington Books.

21. Krugman, P. R., Obstfeld, M., \& Melitz, M. J. (2012). International Economics, Theory \& Policy $\left(9^{\text {th }}\right.$ Ed). USA: Addison-Wesley.

22. Liu.C., Xiaolei, S. X., Chen. J., \& Li, J. (2016). Statistical Properties Of Country Risk Ratings Under Oil Price Volatility, Evidence from Selected Oil-Exporting Countries. Energy Policy, 92(7), 234-245.

23. Miller, K.D., (1998). Economic Exposure and Integrated Risk Management. Journal of Strategic and Management, 9(5), 497-514. 
24. Moosa, I. A. (2002). Foreign Direct Investment - Theory, Evidence and Practice $\left(1^{\text {st }}\right.$ Ed). New York: Palgrave.

25. Nagy, P. J., (1984). Country Risk: How To Assess, Quantify, And Monitor It. London: Euromoney Publications.

26. Nordal, K. B. (2001). Country Risk, Country Risk Indices and Valuation of FDI, a Real Options Approach. Emerging Markets Review, 2(3), 197-217.

27. Oetzel, J. M., Bettis, R. A., \& Zenner, M. (2001). Country risk measures, p.How risky are they? Journal of World Business, 36 (2), 128-145.

28. Petrovic, Evica., \& Stankovic, Jelena. (2009). Country Risk and Effects of Foreign Direct Investment. Economics and Organization, 6(1), 9-22.

29. Sanjo, Yasuo. (2012). Country Risk, Country Size, and Tax Competition for Foreign Direct Investment. International Review of Economics and Finance, 21(1), 292-301.

30. UNCTAD-STAT. (2017). Data Political Stability Rating, dan Economic and Financial Sector. Retriened from http//unctadstat.unctad.org/.Diakses.

31. Vijayakumar, Jayaraman., Rasheed, Abdul A., \& Tondkar, Rasoul. (2009). Foreign Direct Investment and Evaluation of Country Risk, an Empirical Investigation. Multinational Business Review, 17(3), 181 - 204.

32. Word Bank. (2017). Global Economic Prospects Tahun 2007-2016. Retrieved from https//www.worldbank.org/.Diakses pada tanggal 20 Januari 2017.

33. Word Bank. (2017). Data Political Stability Rating, dan Economic and Financial Sector. Retrieved from https//data.worldbank.org/.

34. Word Bank. (2017). Country Overview. Retrieved from https//www.worldbank.org/. 